University of Nebraska - Lincoln

DigitalCommons@University of Nebraska - Lincoln

1991

\title{
Effects of Trenbolone Acetate on Carcass Characteristics and Serum Testosterone and Cortisol Concentrations in Bulls and Steers on Different Management and Implant Schemes
}

\author{
Steven J. Jones \\ University of Nebraska-Lincoln, sjones1@unl.edu \\ R. D. Johnson \\ Kansas State University \\ Chris R. Calkins \\ University of Nebraska-Lincoln, ccalkins1@unl.edu \\ M. Dikeman \\ Kansas State University
}

Follow this and additional works at: https://digitalcommons.unl.edu/animalscifacpub

Part of the Animal Sciences Commons

Jones, Steven J.; Johnson, R. D.; Calkins, Chris R.; and Dikeman, M., "Effects of Trenbolone Acetate on Carcass Characteristics and Serum Testosterone and Cortisol Concentrations in Bulls and Steers on Different Management and Implant Schemes" (1991). Faculty Papers and Publications in Animal Science. 573.

https://digitalcommons.unl.edu/animalscifacpub/573

This Article is brought to you for free and open access by the Animal Science Department at DigitalCommons@University of Nebraska - Lincoln. It has been accepted for inclusion in Faculty Papers and Publications in Animal Science by an authorized administrator of DigitalCommons@University of Nebraska - Lincoln. 


\title{
EFFECTS OF TRENBOLONE ACETATE ON CARCASS CHARACTERISTICS AND SERUM TESTOSTERONE AND CORTISOL CONCENTRATIONS IN BULLS AND STEERS ON DIFFERENT MANAGEMENT AND IMPLANT SCHEMES1
}

\author{
S. J. Jones ${ }^{2}$, R. D. Johnson ${ }^{3}$, C. R. Calkins ${ }^{2}$ and M. E. Dikeman ${ }^{3}$
}

University of Nebraska, Lincoln 68583-0908

and Kansas State University, Manhattan 66506

\begin{abstract}
The objective of this study was to determine the effects of different implanting schemes on serum testosterone and cortisol concentrations, and carcass traits of bulls and steers implanted with trenbolone acetate (TBA) and zeranol $(\mathrm{Z})$. Twenty Polled Hereford bulls were randomly assigned to one of three treatments after birth. Five calves served as nonimplanted control bulls (NIB). Nine bulls were implanted (IB) with $140 \mathrm{mg}$ of TBA and $36 \mathrm{mg}$ of $\mathrm{Z}$ at about 1 mo of age and reimplanted with both compounds 10 wk later. When IB calves were about 21 wk of age, the TBA implant was removed and calves were reimplanted with $Z$ every 10 wk until slaughter. Six calves were castrated at 3 wk of age and implanted (IS) with TBA and Z every 10 wk until slaughter. Blood samples from each animal were obtained at 14-d intervals beginning at $14 \mathrm{wk}$ of age and serum cortisol (C) and testosterone (T) concentrations were determined. The NIB had higher $\mathrm{C}$ levels than IB or IS $(P<.05)$ during the preweaning period. During the finishing period, there were no differences in C concentrations between NIB and IB; however, IS had lower levels $(P<$ .05 ) than both bull treatments. Serum $T$ concentrations began to increase about 12 wk later (42 vs 30 wk, respectively) in IB compared with NIB. Testicular size was smaller $(P<.05)$ in IB than in NIB. No differences $(P>.05)$ were observed in carcass characteristics. Tastepanel scores were not different among treatments. In conclusion, implanting schemes using TBA and $\mathrm{Z}$ lowered serum levels of $\mathrm{C}$ and delayed puberty in bulls; however, they did not alter carcass characteristics or eating quality.
\end{abstract}

Key Words: Trenbolone Acetate, Bulls, Steers, Cortisol, Testosterone

J. Anim. Sci. 1991. 69:1363-1369

\section{Introduction}

Interest in bulls for meat production originates from data that indicate bulls have higher rates of gain (Gregory and Ford, 1983), improved feed efficiency (Champagne et al., 1969; Ford and Gregory, 1983), increased lean meat produced/unit gain (Ntunde et al., 1977),

\footnotetext{
${ }^{1}$ Paper number 9233, Joumal Series, Nebraska Agric. Res. Div., Inst. of Agric. and Nat. Resources.

${ }^{2}$ Univ, of Nebraska, Dept. of Anim. Sci.

${ }^{3}$ Kansas State Univ, Dept. of Anim. Sci. and Ind. Received July 26, 1990.

Accepted September 28, 1990.
}

and improved product leanness (Kay and Houseman, 1975). However, under present production, grading, and processing systems, use of bulls for meat has met with resistance (Dikeman, 1984). The aggressive behavior of bulls during the finishing phase increases the incidence of dark cutting meat and losses due to bruising and increases live and carcass shrinkage (Price and Tennessen, 1981; Mies, 1982; Oltjen, 1982; Seideman et al., 1982).

Implanting steers and heifers with synthetic androgens may increase growth performance without the management problems associated with feeding bulls. One synthetic androgen that has been approved for use in steers and heifers is trenbolone acetate (TBA). This compound 
improves rates of gain and feed efficiency and increases carcass weight in steers (Heitzman, 1978; Steen, 1985; Fisher et al., 1986a,b). Neumann (1976) reported that TBA is 10 to 50 times more anabolically active than testosterone and can promote positive $\mathrm{N}$ balance when combined with estrogenic compounds such as zeranol (Z). Thomas and Rodway (1982a) hypothesized that TBA inhibits the catabolic action of glucocorticoids by reducing their serum concentrations.

The objective of this study was to evaluate several management systems using TBA as either a replacement for naturally occurring androgens or as an anabolic supplement during the prepubertal period of bulls. The implantation of TBA plus $\mathrm{Z}$ in prepubertal bulls and $\mathrm{Z}$ only after puberty was designed to enhance prepubertal growth and possibly minimize undesirable secondary sexual characteristics during the finishing phase.

\section{Materials and Methods}

Management and Live Animal Measurements. Twenty-five Polled Hereford bulls were assigned randomly to one of the three following treatments shortly after birth: eight calves remained as nonimplanted bulls (NIB) and nine bulls were implanted (IB) with $140 \mathrm{mg}$ of TBA and $36 \mathrm{mg}$ of $\mathrm{Z}$ at about $1 \mathrm{mo}$ of age and reimplanted with both compounds 10 wk later. When these nine IB calves were about 21 wk of age, the TBA implant was removed and they were reimplanted with $Z$ every 10 wk until slaughter. The remaining eight calves were castrated at about 3 wk of age and implanted (IS) with TBA and Z every 10 wk until slaughter. Five calves had to be removed from this study for the following reasons: three calves became chronic bloaters, one calf became totally blind, and one calf was unintentionally castrated. The animals removed from the study were not included in the analysis. There remained five NIB, nine IB, and six IS for the study. Calves remained with their dams on native bluestem pasture until weaned, at an average age of 26 wk. Then they were preconditioned for 4 wk before arrival at the feedlot. Initial feedlot weights were taken following a 12-h fast from feed and water.

\footnotetext{
${ }^{4}$ Cambridge Medical Technology, Bellrica, MA.
}

TABLE 1. DIET COMPOSITION ON A PERCENTAGE OF DRY MATTER BASIS FOR CONTROL BULLS AND IMPLANTED BULLS AND STEERS

\begin{tabular}{lc}
\hline Ingredient & $\begin{array}{c}\text { Percentage } \\
\text { of diet }\end{array}$ \\
\hline Grain sorghum & 82.96 \\
Sorghum silage & 11.04 \\
Soybean meal & 4.05 \\
Ground limestone & .75 \\
Sodium chloride & .36 \\
Urea & .34 \\
Dicalcium phosphate & .27 \\
Potassium chloride & .12 \\
Soybean oil & .06 \\
Monensin $(132 \mathrm{~g} / \mathrm{kg})$ & .02 \\
Trace minerals & .02 \\
Vitamin A $(30,000 \mathrm{rU} / \mathrm{g})$ & .01 \\
\hline
\end{tabular}

${ }^{a}$ Trace mineral composition was $5 \% \mathrm{Ca}, 10 \% \mathrm{Fe}, 10 \%$ $\mathrm{Zn}, 10 \% \mathrm{Mn}, 1 \% \mathrm{Cu}, .3 \% \mathrm{I}$, and $.1 \% \mathrm{Co}$.

Over a 4-wk period, calves were fed a corn and silage diet with continually increasing proportions of concentrate up to $89 \%$ (DM basis, Table 1). The cattle were fed this diet until slaughter.

Cattle within a treatment were assigned to two pens (partially covered, concrete floor, 4.3 $\mathrm{m} \times 8.5 \mathrm{~m}$ ) with average weights for the pair of pens approximately equal. Individual weights were obtained at 28-d intervals. During the finishing period, cattle were held off feed and water for $12 \mathrm{~h}$ before each weighing time to calculate feedlot ADG.

Blood Collection and Analyses. Blood samples were obtained from each animal beginning at approximately 14 wk of age and at 14-d intervals until slaughter. During the preweaning period, calves were brought in from a large pasture and held in a holding pen for approximately $.5 \mathrm{~h}$. Blood was collected via jugular venipuncture into $15-\mathrm{ml}$ vacuum tubes, refrigerated for $24 \mathrm{~h}$ at $5^{\circ} \mathrm{C}$ and centrifuged to separate serum, and the serum was stored frozen at $-20^{\circ} \mathrm{C}$ for subsequent analyses. Cortisol concentrations were determined in duplicate $50-\mu 1$ samples of serum using a radioimmunoassay kit $^{4}$. Intra-assay and interassay coefficients of variation for the assay were 6.4 and $11.5 \%$, respectively, at a sensitivity of $1 \mathrm{ng} / \mathrm{ml}$. Testosterone concentrations were determined in duplicate $100-\mu \mathrm{l}$ (bulls) or $200-\mu \mathrm{l}$ (steers) samples of serum using the radioimmunoassay technique of Pruitt et al. (1986). Testosterone extraction 
efficiency was $88.9 \%$ and intra-assay and interassay coefficients of variation were 8.1 and $15.6 \%$, respectively.

Cattle were transported $200 \mathrm{~km}$ to a commercial packing plant and held approximately $4 \mathrm{~h}$ before slaughter. Upon slaughter, testicles were removed and weighed and the carcasses were shrouded and chilled overnight.

After a 24-h chill, USDA (1976) yield and quality grade data, carcass masculinity scores, and longissimus quality traits were evaluated. Carcass masculinity scores were based on jump muscle and crest development $(1=$ least masculine to $5=$ most masculine), whereas the longissimus muscle was scored for lean color ( 1 = very light red to $8=$ dark red), texture ( 1 $=$ very coarse to $8=$ very fine), firmness $(1=$ very soft to $8=$ very firm), and presence of heat ring $(1=$ none to $5=$ extremely severe).

A wholesale rib from each carcass was removed and aged for $7 \mathrm{~d}$ at $2^{\circ} \mathrm{C}$. Two steaks, $2.54 \mathrm{~cm}$ thick, were removed from the 11 th and 12th rib region, double-wrapped in freezer paper, and stored at $-20^{\circ} \mathrm{C}$ until they were evaluated. The most posterior steak was designated for sensory panel (SP) analysis, and the adjacent steak was for Warner-Bratzler shear (WBS) force determination using an Instron Universal testing machine ${ }^{5}$.

Steaks for SP evaluations and WBS determinations were thawed overnight at $5^{\circ} \mathrm{C}$ and oven-broiled at $166^{\circ} \mathrm{C}$ to an internal temperature of $70^{\circ} \mathrm{C}$ (monitored with copper-constantan thermocouples). A mechanical coring device was used to obtain uniform longissimus cores $1.27 \mathrm{~cm}$ in diameter that were excised perpendicular to the steak surface. These cores were served warm to a six-member, trained SP (AMSA, 1978) or allowed to equilibrate to room temperature for $2 \mathrm{~h}$ before WBS determination. The panel rated juiciness, flavor intensity, myofibrillar tenderness, overall tenderness, and connective tissue amount based on an 8-point scale. Six or seven steaks were evaluated per session (three sessions); steaks were randomly selected, proportionate to the number in each treatment, so that each treatment was represented in each session.

During the study, animals were subjected to stresses of weaning, placement in the feedlot, and puberty, factors that are likely to affect

\footnotetext{
SInstron Corp., Canton, MA
}

serum levels of cortisol (C) and testosterone (T). These environmental and physiological events would distort the interpretation of the serum hormone data if they were analyzed as one time period. To better understand changes at different stages of growth, cortisol data were analyzed in the following three periods: preweaning (wk 14 to 26), including the time at the beginning of the study until weaning; postweaning (wk 27 to 36), from weaning during the 4-wk preconditioning and 4-wk diet adjustment period; and finishing (wk 37 to 60). Serum hormone data were analyzed by analysis of variance using a completely randomized block design (Steel and Torrie, 1980). Orthogonal contrasts were used to determine differences between NIB vs IB and NIB vs IS. Significance was identified at the .05 level. The statistical model used was a split-plot analysis of variance, with the whole plot as treatment and the split plot as time. Age and hip-height differences were adjusted using date of birth and hip height as covariates in the analysis. Treatment means, analysis of variance, and orthogonal contrasts were calculated and performed using SAS (1985).

\section{Results and Discussion}

Preweaning. During the preweaning period, NIB had higher $(P<.05) \mathrm{C}$ concentrations than IB and IS (Table 2). The NIB demonstrated a wide range of $\mathrm{C}$ concentrations from week to week. The lower serum $C$ concentrations observed in the two implant treatments were likely due to TBA implantation. Researchers have demonstrated that TBA lowers serum corticosterone concentrations in rats and serum $\mathbf{C}$ concentrations in sheep (Thomas and Rodway, 1982a). A second study by Thomas and Rodway (1982b) demonstrated that TBA reduced the adrenocorticotropic (ACTH)stimulated release of corticosterone from isolated rat adrenal tissue. Both studies suggested that TBA exerts some of its anabolic influence through a suppression of adrenal activity (e.g., lower serum corticosteroid concentrations). This may be the case with our cattle in the preweaning period because lower serum $C$ concentrations occurred in conjunction with TBA implantation. The wider range of serum $C$ values observed in NIB may be due to the absence of an inhibitory effect of TBA on ACTH-stimulated release of $C$. During the preweaning period, the NIB probably reacted 
TABLE 2. MEAN SERUM CORTISOL CONCENTRATION OF NONIMPLANTED BULLS AND IMPLANTED STEERS AND BULLS DURING PREWEANING, POSTWEANING, AND FINISHING ${ }^{\mathrm{a}}$

\begin{tabular}{|c|c|c|c|c|c|c|}
\hline \multirow[b]{3}{*}{ Period } & \multicolumn{3}{|c|}{ Treatment } & \multicolumn{2}{|c|}{ Contrasts } & \multirow[b]{3}{*}{ SE } \\
\hline & \multicolumn{2}{|c|}{ Implanted } & \multirow[b]{2}{*}{ Bulls ${ }^{d}$} & \multirow{2}{*}{$\begin{array}{l}\text { Implanted steers } \\
\text { vs bulls }\end{array}$} & \multirow{2}{*}{$\begin{array}{l}\text { Implanted bulls } \\
\text { vs bulls }\end{array}$} & \\
\hline & Steers $^{b}$ & Bulls $^{c}$ & & & & \\
\hline Preweaning & 5.23 & 5.28 & 13.15 & $P<.05$ & $P<.05$ & .64 \\
\hline Postweaning & 11.52 & 15.83 & 15.82 & $\mathrm{NS}^{\mathrm{e}}$ & NS & 1.23 \\
\hline Finishing & 6.69 & 12.00 & 10.92 & $P<.05$ & NS & .67 \\
\hline
\end{tabular}

${ }^{a}$ Mean serum cortisol concentration for each treatment during a given period (ng/ml).

bSteers were implanted with $140 \mathrm{mg}$ trenbolone acetate (TBA) plus $36 \mathrm{mg}$ of zeranol (Z) at one mo of age, then every 10 wk until slaughter $(n=6)$.

${ }^{c}$ Bulls were implanted with $140 \mathrm{mg}$ of TBA plus $36 \mathrm{mg}$ of $\mathrm{Z}$ at one mo of age and $10 \mathrm{wk}$ later, then with zeranol every 10 wk until slaughter $(n=9)$.

Bulls remained intact throughout the study $(n=5)$.

NS = not significant.

similarly to the way nonimplanted steers react because they had not reached puberty and the testes were not secreting $T$ in significant amounts (Figure 1).

Postweaning. During the postweaning period, the cattle were stressed for several weeks.
Several cattle bloated during this time and increased nasal discharge was prevalent for several days after weaning. The stress was documented by $\mathrm{C}$ levels that were two to three times higher than concentrations reported during the preweaning period (Table 2). It was

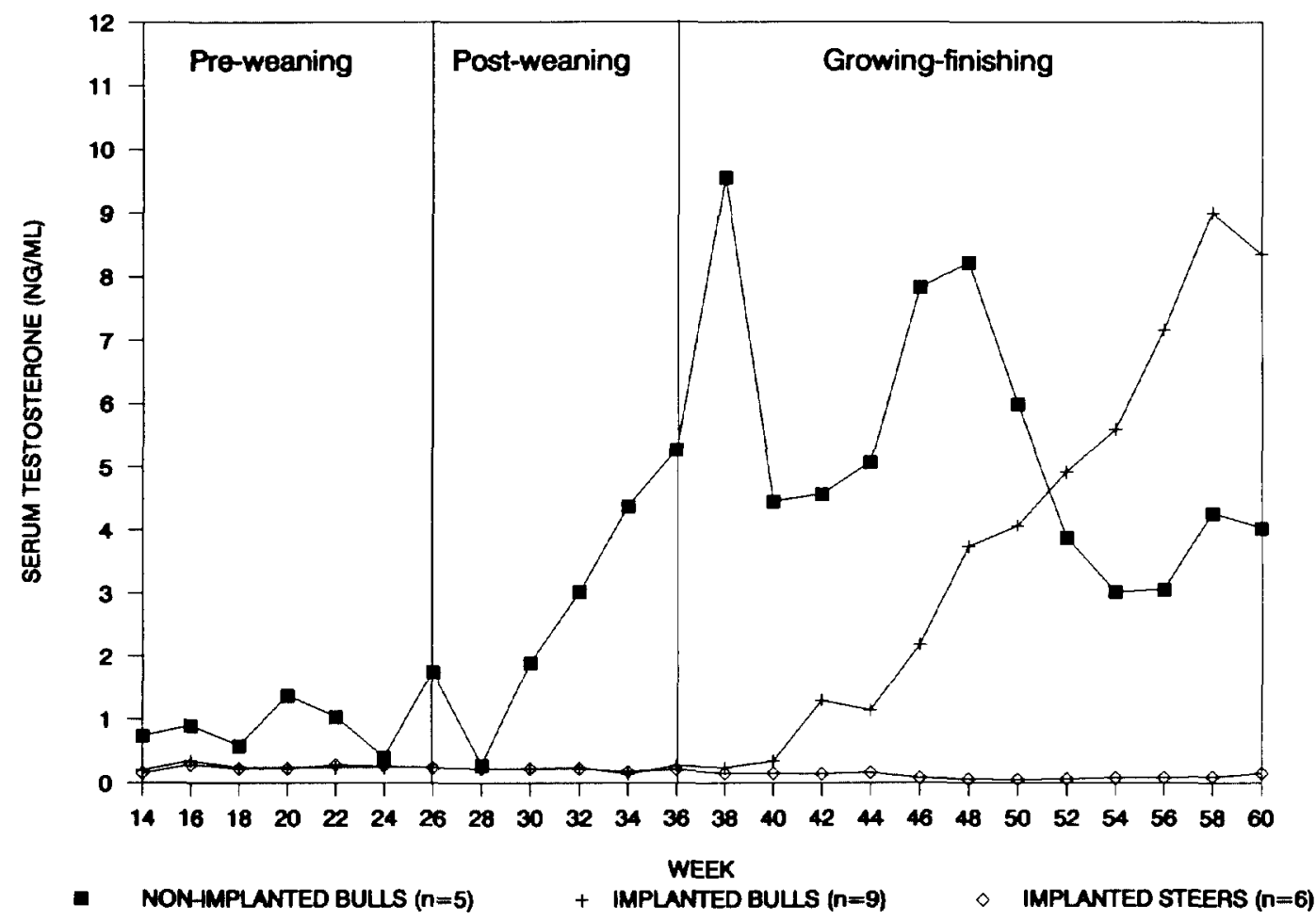

Figure 1. Serum testosterone concentrations of nonimplanted and implanted bulls and implanted steers during all periods. $\mathrm{SE}=, 91$. 
noted that IS tended $(P<.10)$ to have lower $C$ levels than either IB or NIB, which may be caused by the TBA present in IS.

During the postweaning period, the NIB reached puberty. This was documented by an increase in serum T (Figure 1). The IB did not have an increase in serum $T$ until wk 42, compared with wk 30 for NIB. Scrotal circumferences were smaller and testicle weights were lighter $(P<.05)$ in IB than in $\mathrm{NIB}$, indicating reduced testicular development (Table 3). Lower serum T in IB may be due to the implant given to the bulls during the preweaning period. Other researchers have shown that bulls given TBA implants early in life have reduced testicular development, which would delay increasing concentrations of T (Fabry et al, 1983; Silcox et al., 1986). Another contributing factor to reduced testicular weight is the negative effect that $Z$ has on testicular development. Beverly (1984) reported that $\mathrm{Z}$ has an affinity to cytoplasmic estrogen receptors throughout the body. Schanbacher (1984) suggested that estrogenic implants inhibit testicular development in bulls.

It has been postulated that higher $T$ levels in bulls may cause a reduction in serum $C$ levels. This has been demonstrated by Bukoski et al. (1986), who observed that the addition of $T$ decreased ACTH-stimulated release of C from adrenal gland slices. Henricks et al. (1984) reported that bulls had lower serum C than heifers. In our study, failure of NIB to have serum $\mathrm{C}$ as low as IS suggests that the inhibitory action of TBA in IS was greater than endogenous levels of $T$ in NIB. Neumann (1976) reported TBA had a 10 to 50 times greater effect in promoting a positive $\mathrm{N}$ balance than $T$. It may also have a similar effect in reducing serum $\mathrm{C}$ concentrations.

Finishing Period. During the finishing period, there were no differences in serum $C$ levels between IB and NIB; however, IS had lower $(P<.05)$ serum $C$ levels than IB (Table 2). The TBA implants in IS caused lower levels of $C$ throughout the study. The action of TBA does not seem to carry over because IB did not exhibit lower serum $C$ during the finishing period than during the preweaning period. With the TBA implant, the IS may have higher levels of anabolic agents than the other treatments, which caused a decrease in C levels. The IB did not have lower serum C levels because they were not receiving TBA during this period.
Endogenous levels of $\mathrm{T}$ may have some control on the release of $\mathrm{C}$. In the finishing period there was a significant $(P<.05)$ correlation between serum $\mathrm{T}$ and serum $\mathrm{C}$; however, it was negatively correlated ( $\mathrm{r}=$ -18). Henricks et al. (1984) did not observe a linear association between these two hormones; however, they did observe that when serum $C$ was high the coincident serum $T$ was low.

Carcass Characteristics. No differences ( $P$ $>.05)$ were observed in carcass characteristics among the three treatment groups (Table 4). Silcox et al. (1986) reported that carcass weights for NIB were similar to those of bulls implanted with $Z$, TBA, or Z plus TBA. Steen (1985) found that bulls implanted with $Z$ had heavier carcass weights than steers implanted with $Z$ plus TBA; however, dressing percentages were similar for both groups.

No differences $(P>.05)$ were noted in carcass maturity, which was somewhat expected because cattle were slaughtered at a similar chronological age (approximately 13.6 mo of age). Other researchers also have reported that $\mathrm{Z}$ did not alter overall carcass maturity in comparison to NIB (Greathouse et

TABLE 3. WEANING AND SLAUGHTER WEIGHTS, HIP HEIGHTS, AND MASCULINITY CHARACTERISTICS FOR NONIMPLANTED BULLS AND IMPLANTED BULLS AND STEERS

\begin{tabular}{|c|c|c|c|c|}
\hline \multirow[b]{3}{*}{ Trait } & \multicolumn{4}{|c|}{ Treatment } \\
\hline & Impl & lanted & & \\
\hline & Steers $^{\mathrm{a}}$ & Bulls $^{b}$ & Bulls & SE \\
\hline Weaning wt, kg & 214 & 218 & 205 & 9.20 \\
\hline Slaughter wt, kg & 514 & 517 & 479 & 10.90 \\
\hline Hip height at $12 \mathrm{mo}, \mathrm{cm}$ & 114 & 118 & 121 & 1.99 \\
\hline $\begin{array}{l}\text { Average daily gain, } \mathrm{kg} / \mathrm{d} \\
\text { Masculinity score }\end{array}$ & 1.6 & 1.5 & 1.4 & .05 \\
\hline at $13 \mathrm{mo}^{\mathrm{c}}$ & 2.3 & 3.0 & 3.2 & .24 \\
\hline Scrotal circ. at $8 \mathrm{mo}, \mathrm{cm}$ & - & $20.9^{d}$ & $25.9^{\circ}$ & .71 \\
\hline Scrotal circ. at $13 \mathrm{mo}, \mathrm{cm}$ & - & $34.5^{\mathrm{d}}$ & $38.8^{\mathrm{e}}$ & 1.04 \\
\hline Testicular wt, $g$ & - & $294^{d}$ & $398^{\mathrm{e}}$ & 15.62 \\
\hline
\end{tabular}

${ }^{\text {a }}$ Steers were implanted with $140 \mathrm{mg}$ of trenbolone acetate (TBA) plus $36 \mathrm{mg}$ of Zeranol $(Z)$ at $1 \mathrm{mo}$ of age then every 10 wk until slaughter $(n=6)$.

${ }^{b}$ Bulls were implanted with $140 \mathrm{mg}$ of TBA plus 36 $\mathrm{mg}$ of $\mathrm{Z}$ at $1 \mathrm{mo}$ of age and 10 wk later, then with $Z$ every 10 wk until slaughter $(n=9)$.

${ }^{c}$ Masculinity scores were based on gluteus medius muscle and crest development; 1 = least masculine, 5 = most masculine.

d,e Means in the same row with different superscripts differ $(P<.05)$. 
al., 1983; Unruh et al., 1986) or steers (Vanderwert et al., 1985).

Steers generally have higher marbling scores than bulls (Seidemen et al., 1982; Gregory and Ford, 1983), but no marbling differences occurred in our study. Similarly, Silcox et al. (1986) found that bulls implanted with $Z$ or $Z$ plus TBA were similar to NIB in marbling. However, Fisher et al. (1986b) reported that bulls implanted with TBA plus estradiol had more marbling than NIB, whereas IS seemed to have less marbling.

Longissimus quality traits (firmness, texture, color, and absence of heat ring) were very desirable, regardless of sex or implant scheme, and no differences resulted from treatment

TABLE 4. CARCASS TRAITS AND RIBEYE (LONGISSIMUS) QUALITY TRAITS OF NONIMPLANTED BULLS AND IMPLANTED BULLS AND STEERS

\begin{tabular}{|c|c|c|c|c|}
\hline \multirow[b]{3}{*}{ Trait } & \multicolumn{4}{|c|}{ Treatment } \\
\hline & \multicolumn{2}{|c|}{ Implanted } & \multirow[b]{2}{*}{ Bulls } & \multirow[b]{2}{*}{ SE } \\
\hline & Steers $^{\mathrm{a}}$ & Bulls $^{b}$ & & \\
\hline Hot carcass wt, $\mathbf{k g}$ & 306 & 311 & 291 & 7.20 \\
\hline Dressing percentage & 59.5 & 60.1 & 60.7 & .61 \\
\hline Carcass maturityc & $A^{52}$ & $A^{53}$ & $A^{53}$ & 4.79 \\
\hline Marbling score & Small $0^{0}$ & ${ }^{7}$ Small $^{00}$ & Slight ${ }^{82}$ & 2.14 \\
\hline Fat thickness, cm & 1.2 & 1.0 & .9 & .10 \\
\hline Ribeye area, $\mathrm{cm}^{2}$ & 81.3 & 83.2 & 85.2 & 3.72 \\
\hline Kidney knob, \% & 1.5 & 1.3 & 1.5 & .15 \\
\hline Yield grade & 2.5 & 2.3 & 1.9 & .20 \\
\hline \multicolumn{5}{|l|}{ Gluteus medius and } \\
\hline crest score & 1.3 & 1.6 & 1.5 & .14 \\
\hline Lean firmness ${ }^{f}$ & 6.4 & 5.8 & 5.9 & .40 \\
\hline Lean texture 3 & 5.6 & 4.9 & 4.3 & .36 \\
\hline Lean color ${ }^{\mathrm{h}}$ & 4.0 & 4.1 & 4.3 & .34 \\
\hline Heat ring & 1.1 & 1.0 & 1.0 & .05 \\
\hline
\end{tabular}

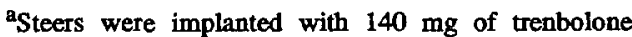
acetate (TBA) plus $36 \mathrm{mg}$ of zeranol $(Z)$ at $1 \mathrm{mo}$ of age, then every 10 wk until slaughter $(n=6)$.

${ }^{b}$ Bulls were implanted with $140 \mathrm{mg}$ of TBA plus 36 $\mathrm{mg}$ of $Z$ at 1 mo of age and 10 wk later, then with $Z$ every 10 wk until slaughter $(n=9)$. 199.

${ }^{c}$ A maturity grade $=0$ to 99, B maturity grade $=100$ to

dSlight marbling score $=200$ to 299 , Small marbling score $=300$ to 399 .

'Masculinity scores were based on gluteus medius muscle and crest development $1=$ least masculine, $5=$ most masculine.

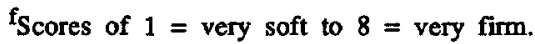

gScores of $1=$ very coarse to $8=$ very fine.

${ }^{h_{S}}$ cores of $1=$ very light red to 8 = dark red.

iscores of $1=$ none to $5=$ extremely severe.
(Table 4). Unruh et al. (1986) also found that lean firmness, texture, and color were not different for $\mathrm{Z}$ IB and NIB.

Implanting bulls and steers near birth until slaughter had no significant effects on SP flavor intensity, juiciness, myofibrillar or overall tenderness, or WBS values (Table 5). However, sensory panel detectable connective tissue amount tended $(P=.07)$ to be higher for NIB than for IB or IS. This may be linked to the early, higher levels of $T$ observed in NIB, which may have hastened collagen maturation (Hall, 1976).

\section{Implications}

Different implant schemes using trenbolone acetate (TBA) and zeranol (Z) alter the release of both cortisol (C) and testosterone (T). Corticosteroids can depress muscle growth due to their catabolic nature. This is of concern to livestock producers because of the detrimental effects $\mathrm{C}$ can have on production efficiency. Methods to reduce serum corticosteroid levels

TABLE 5. TASTE PANEL EVALUATIONS AND WARNER-BRATZLER SHEAR VALUES OF RIBEYE (LONGISSIMUS) STEAKS FOR CONTROL BULLS AND IMPLANTED BULLS AND STEERS

\begin{tabular}{lllll}
\hline & \multicolumn{4}{c}{ Treatment } \\
\cline { 2 - 5 } & \multicolumn{3}{c}{ Implanted $^{\text {Trait }}$} & \multicolumn{3}{c}{ Steers $^{\mathrm{a}}$ Bulls $^{\mathrm{b}}$} & Bulls & SE \\
\hline Flavor intensityc & 6.3 & 6.3 & 6.1 & .18 \\
Juiciness $^{\mathrm{c}}$ & 6.4 & 6.3 & 6.1 & .11 \\
$\begin{array}{l}\text { Connective tissue } \\
\text { amount }^{\mathrm{d}}\end{array}$ & $7.2^{\mathrm{e}}$ & $7.1^{\mathrm{e}}$ & $6.7^{\mathrm{f}}$ & .12 \\
$\begin{array}{l}\text { Myofibrillar } \\
\text { tender nessg }\end{array}$ & 6.4 & 6.2 & 5.4 & .32 \\
$\begin{array}{l}\text { Overall tenderness } \\
\text { Warner-Bratzler shear, } \\
\text { kg }\end{array}$ & 6.5 & 6.4 & 5.9 & .30 \\
\hline
\end{tabular}

asteers were implanted with $140 \mathrm{mg}$ of trenbolone acetate (TBA) plus $36 \mathrm{mg}$ of zeranol (Z) at $1 \mathrm{mo}$ of age then every $10 \mathrm{wk}$ until slaughter $(n=6)$.

b $_{\text {Bulls were implanted with } 140 \mathrm{mg} \text { of TBA plus } 36}$ $\mathrm{mg}$ of $\mathrm{Z}$ at $1 \mathrm{mo}$ of age and 10 wk later then with $Z$ every 10 wk until slaughter $(n=9)$.

${ }^{c} 6=$ slightly intense or slightly juicy, $7=$ very intense or very juicy.

$\mathrm{d}_{6}=$ slight amount, 7 = practically none.

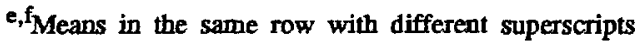
differ $(P<.07)$.

${ }^{8}$ Scores of 1 to $8: 5=$ slightly tender, $6=$ moderately tender. 
could possibly increase muscle growth. It was observed that serum $C$ levels were increased by weaning stress and decreased by TBA implants. Different implant schemes would not be expected to significantly alter carcass characteristics or eating quality of meat. Although behavioral differences and handling problems were not addressed in this paper, TBA may minimize the losses in efficiency during stressful periods by reducing serum $C$ levels. There may be no advantages during the finishing phase for bulls compared to steers implanted with TBA and $Z$.

\section{Llterature Clted}

AMSA. 1978. Guidelines for cookery and sensory evaluation of meat. Am. Meat Sci. Assoc. and Natl. Live Stock and Meat Board, Chicago, IL.

Beverly, J. R. 1984. Ralgro - Its mode of action. In: Proc. Symp. on Implanting for Growth. pp 5-19. IMC Corp., Calgary, Alberta.

Bukoski, H. P., R. H. Mars, S. A. Zinn and R. A. Merkel. 1986. Effects of testosterone on cortisol production in porcine adrenal gland slices in vitro. J. Anim. Sci. 63(Suppl. 1):216.

Champagne, J. R., J. W. Carpenter, J. F. Hentges, Jr., A. Z. Palmer and M. Koger. 1969. Feedlot performance and carcass characteristics of young bulls and steers castrated at four ages. J. Anim. Sci. 29:887.

Dikeman, M. E. 1984. Cattle production systems to meet future consumer demands. J. Anim. Sci. 59:1631.

Fabry, J., R. Renaville, V. Halleux and A. Burny. 1983. Plasma testosterone and LH responses to LHRH in double-muscled bulls treated with trenbolone acetate and zeranol. J. Anim. Sci. 57:1138.

Fisher, A. V., J. D. Wood and M. V. Tas. 1986a. Effects of some anabolic agents on growth, carcass and tissue composition of barley-fed entire and castrated male Fresian cattle. Anim. Prod. 42:195.

Fisher, A. V., J. D. Wood and O. P. Whelehan. 1986b. The effects of a combined and androgenic-œestrogenic agent in steers and bulls. 1. Growth and carcass composition. Anim. Prod. 42:203.

Ford, J. J. and K. E. Gregory. 1983. Effects of late castration and zeranol on feedlot performance and carcass characteristics of bovine males. J. Anim. Sci. 57:286.

Greathouse, J. R., M. C. Hunt, M. E. Dikeman, L. R. Corah, C. L. Kastner and D. H. Kropf. 1983. Ralgro-implanted bulls: Performance, carcass characteristics, longissimus palatability and carcass electrical stimulation. $\mathbf{J}$. Anim. Sci. 57:355.

Gregory, K. E. and J. J. Ford. 1983. Effects of late castration, zeranol and breed group on growth, feed efficiency and carcass characteristics of late maturing bovine males. J. Anim. Sci. 56:771.

Hall, D. A. 1976. The Ageing of Connective Tissue. Academic Press, New York.

Heitzman, R. J. 1978. The use of hormones to regulate the utilization of nutrients in farm animals: Current farm practices. Proc. Nutr. Soc. 37:289.

Henricks, D. M., J. W. Cooper, J. C. Spitzer and L. W. Grimes. 1984. Sex differences in plasma cortisol and growth in the bovine. J. Anim. Sci. 59:376.
Kay, M. and R. Houseman. 1975. The influence of sex on meat production. In: D.J.A. Cole and R. A. Lawrie (Ed.) Meat. p 85. Butterworths, London.

Mies, W. L. 1982. Commercial feeding, management, and marketing of young intact males. In: Proc. U.S. Beef Symp.: Beef from Young, Intact Males. pp 49-51. Kansas State Univ., Manhattan.

Neumann, F. 1976. Pharmacological and endocrinological studies on anabolic agents. In: F. Coulston and F. Korte (Ed.) Anabolic Agents in Animal Production. pp 253-264. Georg Thieme Publishers, Stuttgart, West Germany.

Ntnnde, B. N., W. R. Usborne and G. C. Ashton. 1977. Responses in meat characteristics of Holstein-Fresian males to castration and diet. Can. J. Anim. Sci. 57:449.

Oltjen, R. R. 1982. Breeding, feeding and managing young bulls for meat production: State of the art and research summary. In: Proc. U.S. Beef Symp.: Beef from Young, Intact Males. pp 33-40. Kansas State Univ., Manhattan.

Price, M. A. and T. Tennessen. 1981. Preslaughter management and dark-cutting in the carcasses of young bulls. Can. J. Anim. Sci. 61:205.

Pruitt, R. J., L. R. Corah, J. S. Stevenson and G. H. Kiracofe. 1986. Effect of energy intake after weaning on the sexual development of beef bulls. II. Age at first mating, age at puberty, testosterone and scrotal circumference. J. Anim. Sci. 63:579.

SAS. 1985. SAS User's Guide: Statistics. SAS Inst., Inc., Cary, NC.

Schanbacher, B. D. 1984. Pituitary-testicular responses of estradiol-17 $\beta$-implanted bull calves to continuous versus pulsatile infusion of luteinizing hormone releasing hormone. J. Anim. Sci. 58:943.

Seideman, S. C., H. R. Cross, R. R. Oltjen and B. D. Schanbacher. 1982. Utilization of the intact male for red meat production: A review. J. Anim. Sci. 55:826.

Silcox, R. W., J. T. Keeton and B. H. Johnson. 1986. Effects of zeranol and trenbolone acetate on testis function, live weight gain, and carcass traits of bulls. J. Anim. Sci. $63: 358$.

Steel, R.G.D. and Torrie, J. H. 1980. Principles and Procedures of Statistics: A Biometrical Approach (2nd Ed.). McGraw-Hill Book Co., New York.

Steen, R.J.W. 1985. A comparison of bulls and steers implanted with various oestrogenic growth promoters in a 15-month semi-intensive system of beef production. Anim. Prod, 41:301.

Thomas, K. M. and R. G. Rodway. 1982a. Suppression of adrenocortical function in rats and sheep treated with the anabolic steroid trenbolone acetate. Proc. Nutr. Soc. $41 ; 138 \mathrm{~A}$.

Thomas, K. M. and R. G. Rodway. 1982b. Effects of trenbolone on corticosterone production by isolated rat adrenal cells. Proc. Nutr. Soc. 42:43A.

Unruh, J. A., D. G. Gray and M. E. Dikeman. 1986. Implanting young bulls with zeranol from birth to four slaughter ages: II. Carcass quality, palatability and muscle-collagen characteristics. J. Anim. Sci. 62:388,

USDA. 1976. Official United States Standards for Grades of Carcass Beef. USDA Agric. Marketing Serv., Washington, DC.

Vanderwert, W., L. L. Berger, F. K. McKeith, A. M. Baker, H. W. Gonyou and P. J. Bechtel. 1985. Influence of zeranol implants on growth, behavior and carcass traits in Angus and Limousin bulls and steers. J. Anim. Sci. 61:310. 